\title{
Study on Thermal Performance of Urban Residential buildings in the Zhejiang Region
}

\author{
Jinghui $\mathrm{Ma}^{1, \mathrm{a}}$, Weijie $\mathrm{Si}^{2, \mathrm{~b}}$ \\ ${ }^{1,2}$ School of Civil Engineering and Architecture, \\ Zhejiang Sci-Tech University, Hangzhou, China \\ amzh58@hotmail.com, bswj14@qq.com
}

Keywords: Energy Saving Rate; Simulation Analyses; Urban Residences in Zhejiang

Abstract. The aim of the present study is to clarify the energy saving potential for urban residential buildings. In this paper the impact of energy efficiency of Zhejiang urban residential buildings in china is discussed based on simulation analyses. The results show that the air change rate and the U-value (The Heat Transfer Coefficient) of external wall of building have the greater influence on the annual energy saving rate than other factors. The energy saving rate increases clearly with a decrease in the air change rate, and the effective thickness of external wall insulation is between 80 [mm] and $100[\mathrm{~mm}]$ utilizing expanded polystyrene insulation board for the base residential building model.

\section{Introduction}

Hot summer and cold winter zone locates at south center of China, as shown in Fig.1. Zhejiang Province is a part of the hot summer and cold winter zone, and doesn't belong to the heating region, which divided in the 1950's in china. The average outside temperature during the hottest summer month is about 28 [degree $\mathrm{C}$ ]. And, the average outside temperature during the coldest winter month is 5-8 [degree C], as shown in Fig.2. The indoor thermal environment is very poor in the winter and summer, because of without building thermal insulation, and no heating or cooling in the previous buildings [1].

Recently, cooling and heating systems are indispensable for residences in urban areas due to the improvement of the living standard and the rapid growth of economy. However, normal air-conditioning systems, which operate by electric power, increase energy consumption and cause the air-conditioning disease. To respond to increasing energy use in the buildings, Design Standard for Residential Buildings in the "Hot-Summer/Cold-Winter" Zone has been promulgated by China Ministry of Construction in 2001 years. It is important to reduce building energy consumption through improving thermal performance of buildings.

In the present paper, the energy saving potential for a typical six-floor residential building in Zhejiang urban is discussed based on simulation analyses.

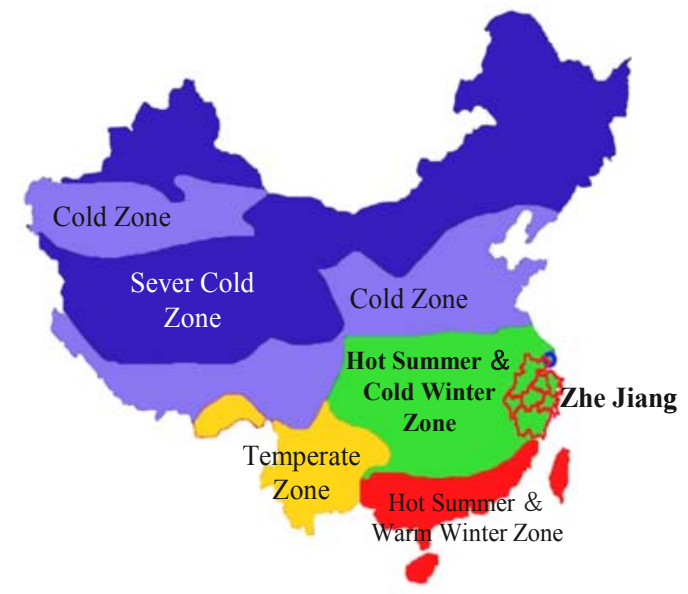

Fig.1 The location of the Zhe Jiang Region.

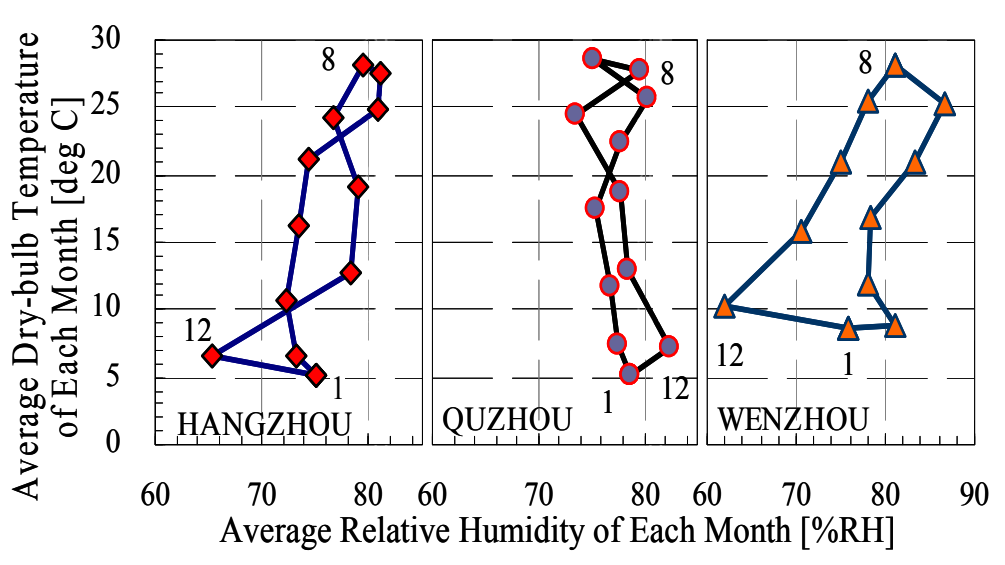

Fig.2 Comparison of the climographs of major cities in the Zhe Jiang region 


\section{Outline of the Base Residential Building}

Fig. 3 shows a typical six-floor building with the total area of $3394\left[\mathrm{~m}^{2}\right]$ was adopted as a base model in the analysis. The story height is 2.9 [m], the total window area is $496.4\left[\mathrm{~m}^{2}\right]$, the total wall area is $1776\left[\mathrm{~m}^{2}\right]$. And the air-condition area is $2607\left[\mathrm{~m}^{2}\right]$. The thermal design for envelope of this model is set to the typical building based on Design Standard for Residential Buildings in the "Hot-Summer/Cold-Winter" Zone, as shown in Table1.

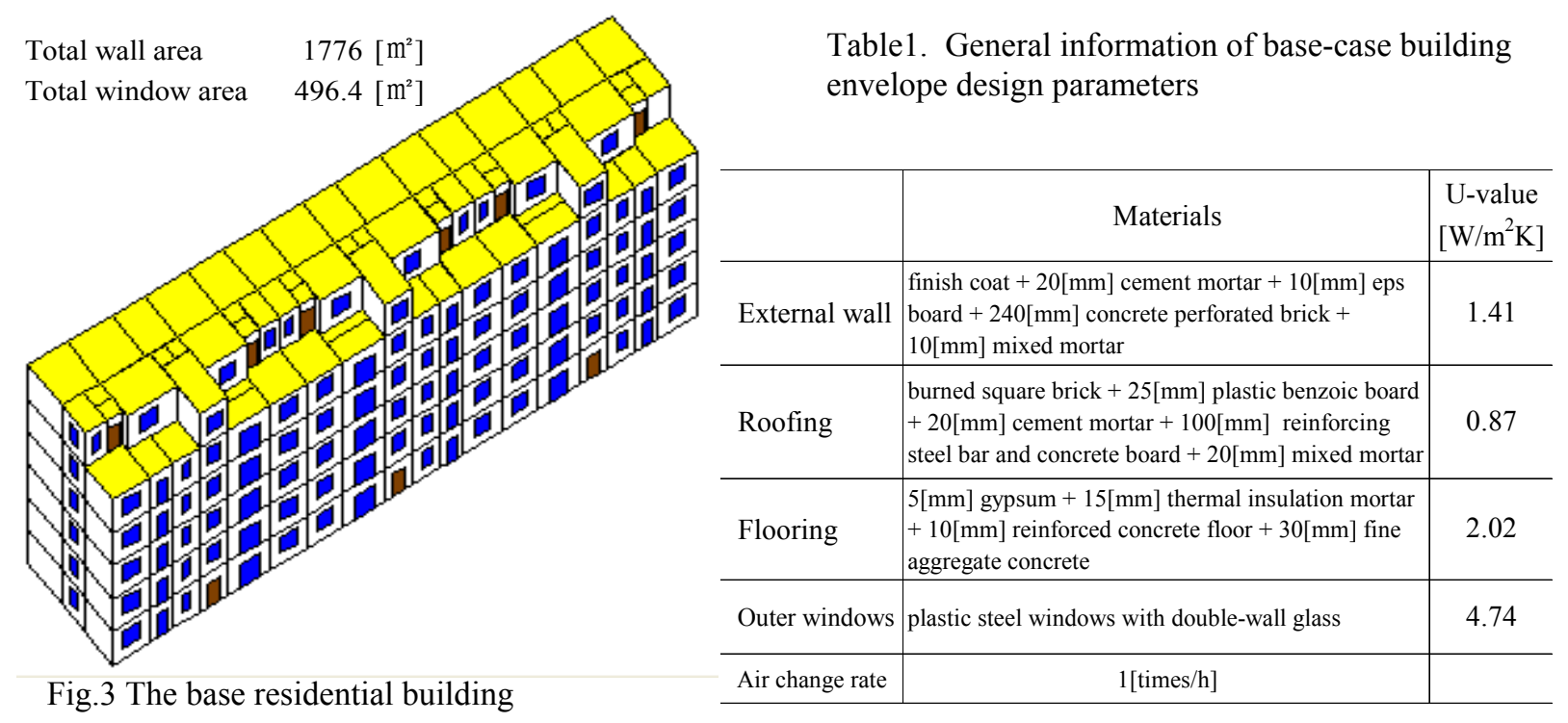

\section{Simulation Conditions}

A computer program to calculate room temperature and cooling and heating load was developed. In this study the effect of thermal insulation and air tightness on the energy saving potential for residential buildings were examined. Table 2 shows the calculation conditions. In these simulations, the heat gain through lighting is $0.014\left[\mathrm{kWh} / \mathrm{m}^{2} \cdot\right.$ day], and the heat gain through appliance is 4.3 $\left[\mathrm{W} / \mathrm{m}^{2}\right]$. The design indoor temperature through a day is 18 [degree $\mathrm{C}$ ] for winter heating, and 26 [degree $\mathrm{C}$ ] for summer cooling. The coefficient of performance for air-conditioner is 1.9 in winter, and 2.3 in summer [2]. The standard climate data of Hangzhou was used for these simulations. The calculation period for cooling was from $6 / 15$ to $8 / 31$, and the period for the heating was from 12/1 to $2 / 28$. The standard climate data of Hangzhou was used for these simulations.

Table2. Calculation conditions

\begin{tabular}{|c|c|c|c|c|c|c|c|c|c|c|c|c|c|c|c|c|c|c|c|}
\hline \multirow{3}{*}{ Case } & \multicolumn{5}{|c|}{ External wall } & \multicolumn{4}{|c|}{ Roofing } & \multicolumn{4}{|c|}{ Ground floor } & \multicolumn{3}{|c|}{ Outer } & \multicolumn{3}{|c|}{ Air change } \\
\hline & \multicolumn{5}{|c|}{$\begin{array}{l}\text { finish coat }+20[\mathrm{~mm}] \text { cement mortar } \\
+\boldsymbol{\alpha}[\mathrm{mm}] \text { eps board }+240[\mathrm{~mm}] \\
\text { concrete perforated brick }+10[\mathrm{~mm}] \\
\text { mixed mortar }\end{array}$} & \multicolumn{4}{|c|}{$\begin{array}{l}\text { burned square brick }+\beta[\mathrm{mm}] \text { plastic } \\
\text { benzoic boardd } 20[\mathrm{~mm}] \text { cement } \\
\text { mortat }+100[\mathrm{~mm} m] \mathrm{rinf} \text { orcing steel bar } \\
\text { and concrete board }+20[\mathrm{~mm}] \text { mixed } \\
\text { mortar }\end{array}$} & \multicolumn{4}{|c|}{$\begin{array}{l}30[\mathrm{~mm}] \text { fine aggregate concrete }+ \\
100[\mathrm{~mm}] \text { cast-in-place reinforced } \\
\text { floorslab }+\gamma[\mathrm{mm}] \text { expansion } \\
\text { polyphenyl board }+3[\mathrm{~mm}] \\
\text { polymer mortar }\end{array}$} & \multicolumn{3}{|c|}{$\begin{array}{l}\text { double-wall } \\
\text { glass }(3[\mathrm{~mm}] \\
\text { glass }+ \text { air layer } \\
+\boldsymbol{\delta}[\mathrm{mm}] \text { glass })\end{array}$} & \multicolumn{3}{|c|}{$\varepsilon[$ times $/ \mathrm{h}]$} \\
\hline & 10 & 25 & 50 & 80 & 100 & 25 & 50 & 80 & 100 & 25 & 50 & 80 & 100 & 3 & 4 & 5 & \multirow{2}{*}{1} & \multirow{2}{*}{0.5} & \multirow{2}{*}{0.3} \\
\hline $\mathrm{U}\left[\left[\mathrm{W} / \mathrm{m}^{2} \mathrm{~K}\right]\right]$ & 1.41 & 0.93 & 0.59 & 0.41 & 0.34 & 0.87 & 0.5 & 0.34 & 0.27 & 0.41 & 0.29 & 0.23 & 0.2 & 4.7 & 4 & 3.4 & & & \\
\hline Mode-1 & 0 & & & & & - & & & & - & & & & 0 & & & 0 & & \\
\hline Mode-2 & & $\bullet$ & & & & - & & & & - & & & & 0 & & & 0 & & \\
\hline Mode-3 & & & $\bullet$ & & & 0 & & & & $\bullet$ & & & & - & & & - & & \\
\hline Mode-4 & & & & $\bullet$ & & 0 & & & & $\bullet$ & & & & - & & & - & & \\
\hline Mode-5 & & & & & 0 & 0 & & & & - & & & & 0 & & & 0 & & \\
\hline Mode-6 & 0 & & & & & & - & & & - & & & & 0 & & & 0 & & \\
\hline Mode-7 & 0 & & & & & & & 0 & & $\bullet$ & & & & 0 & & & 0 & & \\
\hline Mode- 8 & 0 & & & & & & & & 0 & - & & & & 0 & & & 0 & & \\
\hline Mode-9 & 0 & & & & & 0 & & & & & 0 & & & 0 & & & 0 & & \\
\hline Mode-10 & 0 & & & & & 0 & & & & & & 0 & & 0 & & & 0 & & \\
\hline Mode-11 & 0 & & & & & - & & & & & & & $\bullet$ & 0 & & & 0 & & \\
\hline Mode-12 & e & & & & & 0 & & & & - & & & & & - & & 0 & & \\
\hline Mode-13 & - & & & & & - & & & & - & & & & & & - & - & & \\
\hline Mode-14 & 0 & & & & & 0 & & & & 0 & & & & 0 & & & & 0 & \\
\hline Mode-15 & - & & & & & - & & & & - & & & & - & & & & & - \\
\hline
\end{tabular}




\section{Indoor Air Temperature Change under Natural Condition}

Fig. 4 shows the temperature change under the natural condition during coldest winter period. The maximum indoor air temperature was maintained at below 10 [degree $\mathrm{C}$ ], although the maximum outside temperature exceeded 10 [degree $\mathrm{C}$ ] on $1 / 22$ to $1 / 25$. In summer, the minimum indoor air temperature exceeded 29 [degree C], during hottest summer period as shown in Fig.5. The daily range of indoor air temperature is less than 3 [degree $\mathrm{C}$ ], the indoor thermal environment is very poor in the winter and summer.

\section{Examination of Energy Saving Effect}

A. Effect of performance of building envelope thermal insulation Fig.6 shows the calculation results under the condition of various insulation (Expanded Polystyrene Insulation Board) thickness of external wall with the same air change rate 1.0 times per hour. The energy saving rate increases with an increase of the thickness of insulation, compared with base-case building Mode1. And the value of energy saving rate in winter is higher than that in summer. In the case of a thickness of 80 [mm] (Mode4 U-value $0.41\left[\mathrm{~W} / \mathrm{m}^{2} \mathrm{~K}\right]$ ), the annual energy consumption is $35.1\left[\mathrm{kWh} / \mathrm{m}^{2}\right]$. The annual energy saving rate is $12 \%$, which is almost the same as that in the case of an insulation thickness of 100 [mm]. It can be considered that the effective thickness of insulation is between 80 [mm] and [100] $\mathrm{mm}$ for this base residential building.

On the other hand, the difference of the energy saving rate is not clear, although the energy saving rate increases with an increase of the thickness of insulation while the thickness of insulation increase at roofing, as shown in Fig. 7. The effective heat transfer coefficient at roof is about $0.5\left[\mathrm{~W} / \mathrm{m}^{2} \mathrm{~K}\right]$. Although not shown in the figure, the difference of the energy saving rate is also not clear, with an increase of the thickness of insulation at ground floor.

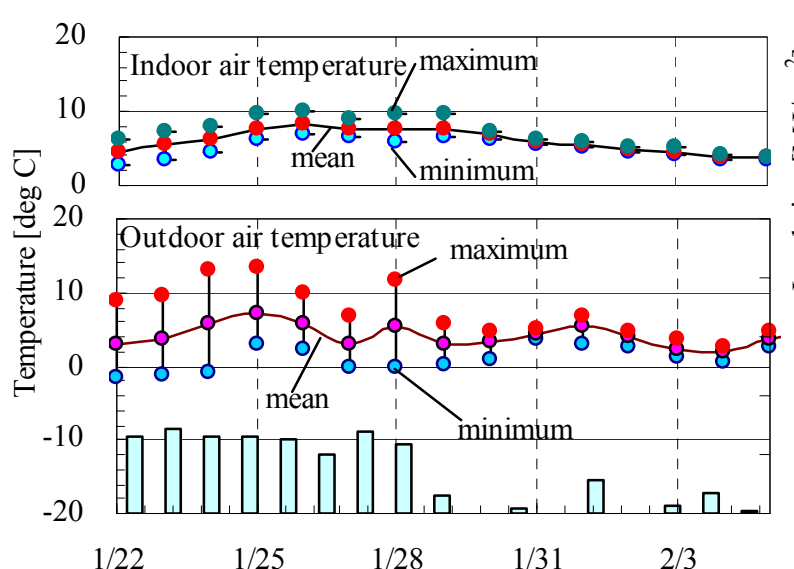

Fig.4 Temperature change in the natural condition (Winter)

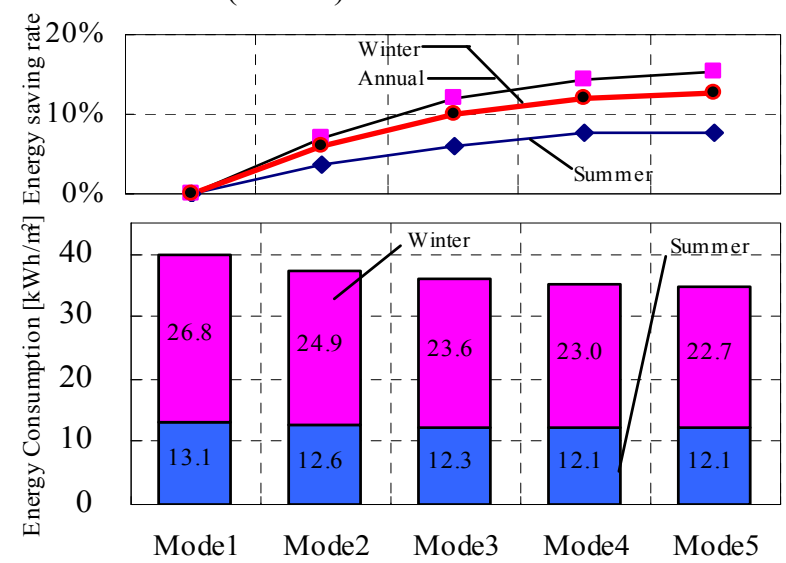

Fig.6 Calculation results for various U-value of externall wall

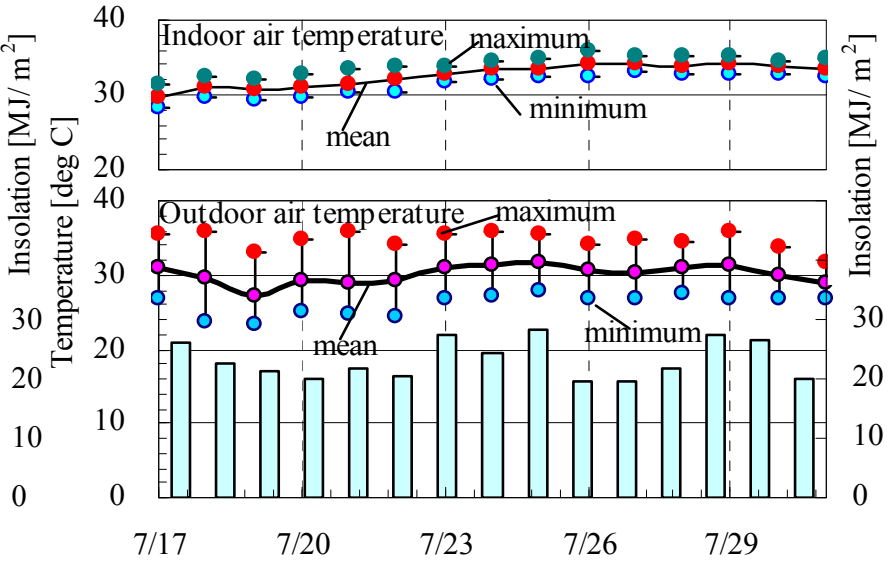

Fig.5 Temperature change in the natural condition (Summer)

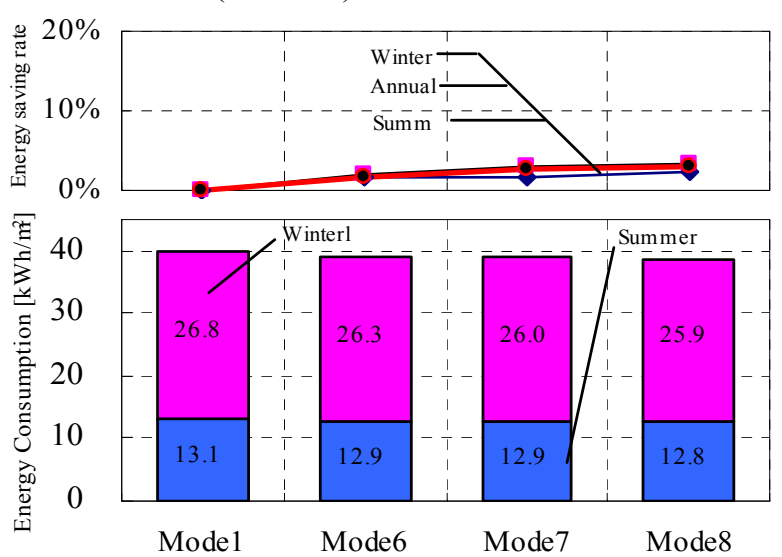

Fig.7 Calculation results for various U-value of roofing 


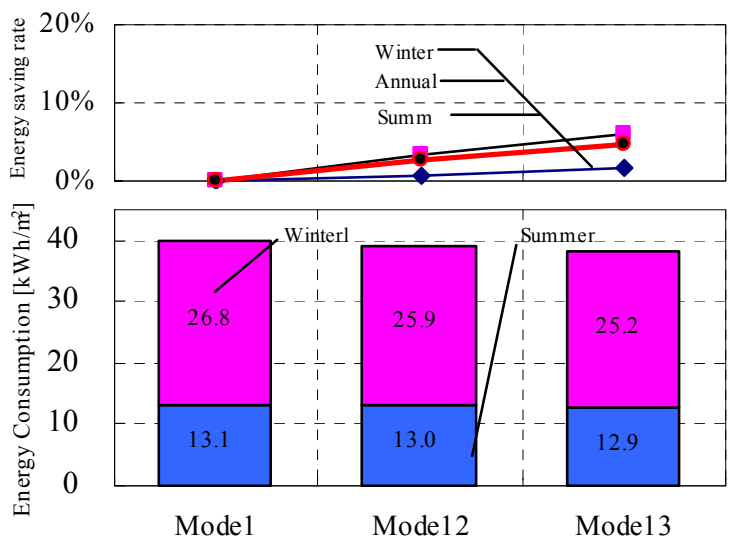

Fig.8 Calculation results for various U-value of outer windows

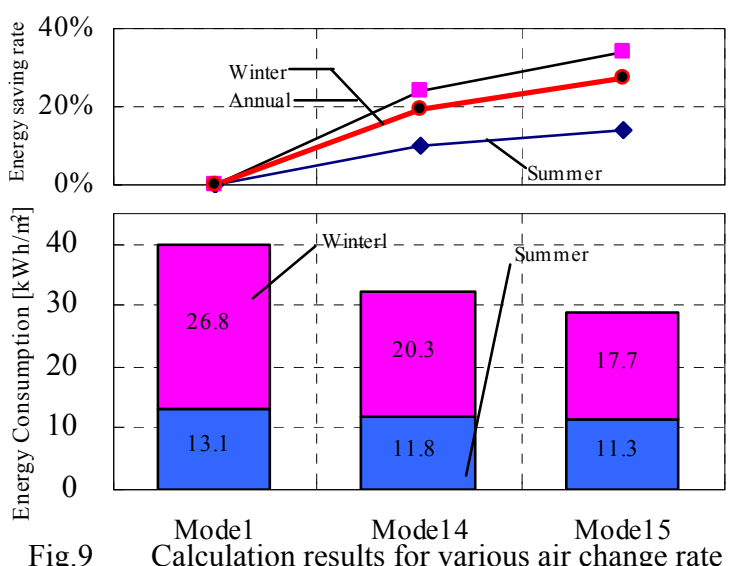

Fig.9 Calculation results for various air change rate

Fig. 8 shows the calculation results under the condition of various types of outer windows with the same air change rate 1.0 times per hour. The annual energy saving rate increases with an increase of thermal performance of outer windows, and the difference of the energy saving rate is not clear.

B. Effect of air tightness The energy saving rate increases clearly with a decrease in the air change rate, as shown in Fig.9. In the case of air change rate $0.5[$ times $/ \mathrm{h}]$, the annual energy consumption is $32.1\left[\mathrm{kWh} / \mathrm{m}^{2}\right]$, which is $20 \%$ less than that of Mode 1 . In the case of air change rate $0.3[$ times $/ \mathrm{h}$ ], the annual energy saving rate is $27.3 \%$. It can be considered that it is important to reduce building energy consumption through improving air tightness of buildings.

C. Impact analysis about the annual energy saving rate Eq. (1) is the result of the multiple variables regressive analysis. The regression determination coefficient is $R^{2}=0.99$, the air change rate and the U-value of external wall of building have the greater influence on the annual energy saving rate than other factors.

$$
\begin{array}{llll}
\eta=\left(0.81-0.39 \mathrm{~T}-0.12 \mathrm{~K}_{\alpha}-0.05 \mathrm{~K}_{\beta}-0.06 \mathrm{~K}_{\gamma}-0.04 \mathrm{~K}_{\delta}\right) * 100 \% & \left(R^{2}=0.99\right) \\
\eta \text { : the annual energy saving rate } & {[\%]} & \mathrm{T}: \text { the air change rate } & {[\text { times } / \mathrm{h}]} \\
\mathrm{K}_{\alpha}: \text { the } \mathrm{U} \text { - value of external wall } & {\left[\mathrm{W} / \mathrm{m}^{2} \mathrm{~K}\right]} & \mathrm{K}_{\beta}: \text { the } \mathrm{U} \text { - value of roofing } & {\left[\mathrm{W} / \mathrm{m}^{2} \mathrm{~K}\right]} \\
\mathrm{K}_{\gamma}: \text { the } \mathrm{U} \text { - value of ground floor } & {\left[\mathrm{W} / \mathrm{m}^{2} \mathrm{~K}\right]} & \mathrm{K}_{\delta}: \text { the } \mathrm{U} \text { - value of outer windows } & {\left[\mathrm{W} / \mathrm{m}^{2} \mathrm{~K}\right]}
\end{array}
$$

\section{Conclusion}

In this paper, the energy saving potential for residential buildings was discussed based on simulation analyses. The most important results are listed below.

(1) The air change rate and the heat transfer coefficient of external wall of building have the greater influence on the annual energy saving rate than other factors.

(2) The effective thickness of external wall insulation is between 80 [mm] and 100 [mm] utilizing expanded polystyrene insulation board for this base residential building. And the heat transfer coefficient of external wall is $0.41\left[\mathrm{~W} / \mathrm{m}^{2} \mathrm{~K}\right]$.

(3) The effective heat transfer coefficient at roof is about $0.5\left[\mathrm{~W} / \mathrm{m}^{2} \mathrm{~K}\right]$.

\section{References}

[1] Yi Jiang, Chinese Building Energy Consumption Situation and Energy Efficiency Strategy. J. New Architecture, (02) 2008 4-7

[2] Design Standard for Residential Buildings in the Hot-Summer and Cold-Winter Zone (JGJ 134-2001)

[3] H. Yoshino, H.H. Lou, Indoor thermal environment of residential buildings in three cities of China, Journal of Asian Architecture and Building Engineering 1 (1) (March) (2002) 